\title{
Elevada Incidência de Infecções Sexualmente Transmissíveis em Doentes com Infecção por VIH
}

\author{
Telma Azevedo', Ana Brasileiro², Fernando Borges', Kamal Mansinho', Irene Santo³, Jacinta Azevedo 3 \\ 'Serviço de Doenças Infecciosas e Medicina Tropical/Department of Infectious Diseases and Tropical Medicine, Hospital de Egas \\ Moniz, Centro Hospitalar de Lisboa Ocidental, Lisboa, Portugal \\ 2Serviço de Dermatologia/Department of Dermatology, Hospital dos Capuchos, Centro Hospitalar de Lisboa Central, Lisboa, Portugal \\ ${ }^{3}$ Centro de Doenças Sexualmente Transmissíveis/STD Center, Centro de Saúde da Lapa, Lisboa, Portugal
}

\begin{abstract}
RESUMO - Introdução: As infecções sexualmente transmissíveis (IST) são um importante problema de saúde e aumentam o risco de adquirir o vírus da imunodeficiência humana $(\mathrm{VIH})$. O objectivo foi identificar as ISTs diagnosticadas em doentes com infecção $\mathrm{VIH}$ conhecida e nos com diagnóstico de novo. Métodos: Análise retrospectiva dos processos clínicos dos utentes que recorreram a uma clínica especializada em IST de 2009 a 2013. Resultados: Foram incluídos 680 doentes, correspondendo a $8 \%$ dos observados no período de estudo. A maioria (638, 92\%) era do sexo masculino e homens que têm sexo com homens (489, 72\%). Quase metade (304, 45\%) eram migrantes. Do total, 270 (40\%) dos doentes tiveram diagnóstico de pelo menos uma IST, sendo sífilis a mais comum (123, 18\%), seguida por infecção por Chlamydia trachomatis (46, 7\%), Neisseria gonorrhoeae (42, 6\%) e condilomas genitais (32, 5\%). Relativamente à infecção VIH, 329 (48\%) doentes tinham infecção conhecida e 351 (52\%) foram diagnosticados de novo. Estes eram significativamente mais jovens e recorreram mais frequentemente para rastreio. Nos doentes com infecção $\mathrm{VIH}$ conhecida encontrou-se maior frequência de antecedentes pessoais de IST, referenciação por parceiros, sintomatologia e diagnóstico de novas ISTs. Conclusões: Foi diagnosticada pelo menos uma IST (excepto VIH) em $40 \%$ dos indivíduos observados. Tal facto representa um problema importante não só porque uma IST concomitante aumenta o risco de aquisição de VIH (para os indivíduos diagnosticados de novo), mas também porque demonstra que os indivíduos com infecção VIH conhecida mantêm um padrão comportamental de elevado risco.
\end{abstract}

PALAVRAS-CHAVE - Comportamento Sexual; Doenças Sexualmente Transmissíveis; Infecções por VIH.

\section{High Incidence of Sexually Transmitted Infections in Patients with HIV-Infection}

\begin{abstract}
Introduction: Sexual transmitted infections (STI) are an important health problem and increase the risk for acquisition and transmission of HIV. We aimed to identify STIs diagnosed in patients with known human immunodeficiency virus (HIV) infection and in newly diagnosed ones. Methods: Retrospective analysis of medical charts of individuals attending a specialized STI Clinic from 2009 to 2013 . Results: A total of 680 patients were included, accounting for $8 \%$ of the patients observed during the study period. The majority $(638,92 \%)$ were male and men who have sex with men (MSM) $(489,72 \%)$. Almost half $(304,45 \%)$ were migrants. Overall, $270(40 \%)$ patients were diagnosed with at least one STI, syphilis was the most common (123, 18\%), followed by Chlamydia trachomatis (46, 7\%), Neisseria gonorrhoeae infection (42,6\%) and genital warts (32, 5\%). Concerning HIV status, 329 (48\%) patients had known infection and 351 (52\%) were newly diagnosed during the study period. The newly diagnosed patients were significantly younger (37.3 \pm 9.7 vs $32.4 \pm 9.5$ years) and more frequently sought attention for screening. Past history of STIs, partner referral, symptoms and being diagnosed with at least one concomitant STI were significantly more common in previously known HIV patients.
\end{abstract}

Apresentações e Prémios: Foi apresentado um poster com os dados preliminares no $25^{\circ}$ Congresso Europeu de Microbiologia Clínica e Doenças Infecciosas, em Copenhaga, Dinamarca que se realizou de 25 a 28 Abril de 2015.

Correspondência: Telma Susana Vieira Azevedo

Serviço de Doenças Infecciosas e Medicina Tropical

Hospital de Egas Moniz, Centro Hospitalar de Lisboa Ocidental

Rua da Junqueira $\mathrm{n}^{\circ} 126$ - 1349-019 Lisboa, Portugal

Tel.: + 351964350169

E-mail: telma.uwcad@gmail.com
Recebido/Received

30 Novembro/November 2016

Aceite/Accepted

29 Janeiro/January 2017 
Conclusion: At least one new STI (other than HIV) was diagnosed in 40\% of the patients. This represents an important problem not only because concomitant STIs increase the risk of HIV acquisition (for the new diagnosed cases) but also because patient with known HIV infection maintain a high-risk behaviour pattern.

KEYWORDS - HIV Infections; Sexual Behavior; Sexually Transmitted Diseases.

\section{INTRODUCTION}

In order to reduce the incidence of sexually transmitted infections (STI), it is of paramount importance to diagnose and treat symptomatic and asymptomatic patients. This is especially true among high-risk individuals, such as sex workers, men who have sex with men (MSM), and bridge populations (sex workers clients and partners of high-risk patients). Evidence supporting the role of STIs as a cofactor for human immunodeficiency virus infection (HIV) is extensive, and indisputable.' Several studies show a clear relation between STIs and HIV transmission, particularly those that cause mucocutaneous ulceration, such as syphilis and herpes simplex virus infection (HSV). ${ }^{2}$ STIs can increase the risk of acquiring or transmitting HIV different mechanisms, including the breaching of mechanical barriers to infection, increased inflammation and higher levels of HIV cellular targets, and increased genital tract HIV levels. ${ }^{3}$

Additionally, the acquisition of a new IST by a HIV

Table 1 - Characterization of the 680 patients, divided in groups of known and newly diagnosed HIV infection.

\begin{tabular}{|c|c|c|c|c|}
\hline $\begin{array}{l}\text { Demographic } \\
\text { and clinical data (n-\%) }\end{array}$ & $\begin{array}{c}\text { Total } \\
(\mathrm{n}=680)\end{array}$ & $\begin{array}{l}\text { Known HIV } \\
\text { infection } \\
(\mathrm{n}=329)\end{array}$ & $\begin{array}{l}\text { Newly diagnosed } \\
\text { HIV infection } \\
(\mathrm{n}=351)\end{array}$ & $P$ \\
\hline Male gender & $624-92 \%$ & $299-91 \%$ & $325-93 \%$ & NS \\
\hline Median age \pm SD & $34.7 \pm 9.9$ & $37.3 \pm 9.7$ & $32.4 \pm 9.5$ & $<0.05$ \\
\hline $\begin{array}{l}\text { NATIONALITY } \\
\text { Portuguese } \\
\text { Migrants } \\
\text { - Brazil } \\
\text { - PALOPs } \\
\text { - Other European country } \\
\text { - Other }\end{array}$ & $\begin{array}{c}376-55 \% \\
304-45 \% \\
125-18 \% \\
95-14 \% \\
63-9 \% \\
22-3 \%\end{array}$ & $\begin{array}{c}186-56 \% \\
143-44 \% \\
50-15 \% \\
50-15 \% \\
31-9 \% \\
12-4 \%\end{array}$ & $\begin{array}{l}189-54 \% \\
162-46 \% \\
75-21 \% \\
45-13 \% \\
32-9 \% \\
10-3 \%\end{array}$ & NS \\
\hline $\begin{array}{l}\text { SEXUAL ORIENTATION } \\
\text { - MSM } \\
\text { - Heterosexual } \\
\text { - Bisexual }\end{array}$ & $\begin{array}{c}489-72 \% \\
186-27 \% \\
5-1 \%\end{array}$ & $\begin{array}{c}223-68 \% \\
104-32 \% \\
2\end{array}$ & $\begin{array}{c}266-76 \% \\
82-23 \% \\
3-1 \%\end{array}$ & $<0.05$ \\
\hline $\begin{aligned} N^{\circ} & \text { OF PARTNERS (6 month prior to visit) } \\
: & 0 \\
: & 1 \\
: & 2-4 \\
& 5 \text { or more } \\
\cdot & \text { Unknown }\end{aligned}$ & $\begin{array}{c}112-17 \% \\
229-34 \% \\
234-34 \% \\
98-14 \% \\
7-1 \%\end{array}$ & $\begin{array}{c}54-16 \% \\
112-34 \% \\
116-35 \% \\
43-13 \% \\
4-1 \%\end{array}$ & $\begin{array}{c}58-17 \% \\
117-33 \% \\
118-34 \% \\
55-26 \% \\
3-1 \%\end{array}$ & NS \\
\hline PAST OR PRESENT INTRAVENOUS DRUG USE & $10-1 \%$ & $8-2 \%$ & $2-1 \%$ & NS \\
\hline SEX WORKER & $7-1 \%$ & $4-1 \%$ & $3-1 \%$ & NS \\
\hline AT LEAST 1 STI EPISODE IN THE PAST* & $242-36 \%$ & $178-54 \%$ & $64-18 \%$ & $<0.05$ \\
\hline $\begin{array}{l}\text { REASON FOR VISIT } \\
\text { - Symptomatic } \\
\text { - Genital discharge } \\
\text { - Genital warts } \\
\text { - Genital ulcers } \\
\text { - Asymptomatic screening } \\
\text { - Referred by partner } \\
\text { - Referred a partner }\end{array}$ & $\begin{array}{l}239-35 \% \\
63-9 \% \\
49-7 \% \\
59-9 \% \\
376-55 \% \\
33-5 \% \\
49-7 \%\end{array}$ & $\begin{array}{c}176-54 \% \\
51-16 \% \\
38-12 \% \\
35-11 \% \\
97-30 \% \\
26-7 \% \\
14-4 \%\end{array}$ & $\begin{array}{c}63-18 \% \\
12-3 \% \\
11-3 \% \\
24-7 \% \\
279-80 \% \\
7-2 \% \\
35-10 \%\end{array}$ & $<0.05$ \\
\hline
\end{tabular}

* Excluding HIV diagnosis.

MSM, men who have sex with men; SD, standard deviation; NS, non-significant, PALOPs Portuguese-speaking African countries. 
positive individual is believed to increase viral load in the genital area, probably in relation with the activation of inflammatory mechanisms. ${ }^{4}$ Moreover, it is also a marker of risk behaviour, with the associated possibility of HIV transmission. ${ }^{5}$

In Portugal, the rate of new HIV diagnoses remains high, but over the last years we have observed a slight decline in new cases. The incidence rate per 100000 habitants declined from 5.5 in 2009 to 3.1 in 2014 , with a total of 7160 new HIV cases over those 5 years. 6 Series from specialized STI clinics in the country report that 4.1 to $5.5 \%$ of assisted patients were newly diagnosed HIV patients. ${ }^{4,7}$ Nevertheless, few specialized centres in the country are able to assist patients with STI and often the HIV care settings do not promote STI screening and treatment for HIV-infected patients.

Concerning new STIs in known HIV positive patients, the available Portuguese data dates back to 2006 and points towards a high rate of new STIs acquisition - 23\% (108) of a total of $469 \mathrm{STI}$ episodes occurring in HIV-infected individuals. ${ }^{5}$ More recent data on the patterns of STIs acquisition in this population, who have an important role in the infection spreading, is lacking.

The main objective of this study was to identify STIs acquired by newly diagnosed HIV patients, as a possible co-factor, and in known HIV-infected ones, as a marker of behaviour risk. We also aimed to characterize and compare demographics and behaviour patterns in both groups, possibly identifying factors that can be addressed in order to reduce STIs spreading, contributing in this way to reduce both the transmission of HIV and other STIs.

\section{METHODS}

We conducted an observational retrospective study, reviewing medical charts from all individuals attending an open STI primary clinic in Lisbon, Portugal, during a 5-year study period (from January 2009 to December 2013). All patients with previously known HIV infection or newly diagnosed infection were included in the study. Demographic and clinical information was collected and analysed using Stata 12.0. Baseline characteristics were compared using $t$ tests for continuous variables and $\chi 2$ tests for categorical variables. Statistical significance was defined for $p<0.05$. Formal ethical approval was waived by the local Ethics Committee as the study was non-interventional.

\section{RESULTS}

A total of 8718 patients were observed during the study period, of which 680 (8\%) were found to be HIV positive (329-3.8\% known infected patients, and 351-4\% newly diagnosed cases) and thus included in the study (Table 1). Male gender was predominant $(624,92 \%)$, and the mean overall age was $34.7 \pm 9.9$ years. Concerning nationality, the ratio Portuguese/migrants was $376 / 304$ (55/45\%). Brazilian was the most common foreign nationality $(125,18 \%)$, and Portuguese-speaking African countries (PALOPs) individuals together represented $14 \%$ of the study population.
Half of the patients $(342,50 \%)$ reported having 0 to 1 partner in the six months preceding the visit, while 332 $(49 \%)$ disclosed having 2 or more. Over a third $(242,36 \%)$ had at least one confirmed STI in the past (other than HIV), most commonly syphilis (10\%) and urethritis (7\%). Few patients reported using intravenous drugs $(10,1 \%)$ or being sex workers $(7,1 \%)$. More than half of the patients recurred for screening $(376,55 \%)$, while 239 (35\%) had specific symptoms and $33(5 \%)$ were referred by a partner.

Overall, during the study period, 270 (40\%) patients were diagnosed with at least one STI (other than HIV), and $47(7 \%)$ of them had 2 or more diagnosis (Table 2). Bacterial infections were predominant. Syphilis (123, 18\%), namely recent syphilis $(101,15 \%)$, was the most common STI (excluding HIV). Chlamydia trachomatis and Neisseria gonorrhoeae infections were diagnosed respectively in 46 and 42 patients (7 and 6\%), mostly with urethral infections (43/46 and $32 / 42$, respectively for chlamydia and gonorrhea) and urethral/rectal infections (3/46 and 10/42, respectively). Genital warts $(32,5 \%)$, an initial clinical manifestation of genital herpes $(20,3 \%)$ and Molluscum contagiosum (5, 1\%) were the most common viral infections. Other less frequent diagnoses are described in Table 2.

Newly diagnosed HIV patients were significantly younger than patients with known HIV infection (mean age 32.4 vs 37.3 years, respectively), were more frequently MSM (266, $76 \%$ vs 223, 68\%), more frequently sought attention for screening $(279,80 \%$ vs $97,30 \%)$ and were more likely to refer a partner $(35,10 \%$ vs $14,4 \%)$.

Patients with known HIV infection have had more frequently at least one STI (other than HIV) diagnosed in the past than newly diagnosed HIV patients $(178,54 \%$ vs 64 , $18 \%)$, were more often symptomatic at the time of medical visit $(176,54 \%$ vs 63, 18\%), presented more frequently with genital discharge $(51,16 \%$ vs $12,3 \%)$ and were more often referred by a partner $(26,7 \%$ vs $7,2 \%)$ (Table 1$)$. Also, they were more frequently diagnosed with at least one STI (excluding HIV infection) than newly diagnosed patients (148, $45 \%$ vs $122,33 \%, p<0.05)$, most commonly Syphilis (49, $15 \%)$, Neisseria gonorrhoeae infection (26,8\%), Chlamydia trachomatis $(23,7 \%)$, genital warts $(19,6 \%)$, first clinical manifestation of genital herpes (10,4\%).

The most common IST infections in newly HIV diagnosed patients were: Syphilis (74, 21\%), Chlamydia trachomatis (23, 7\%), Neisseria gonorrhoeae (16,5\%), genital warts (13, $4 \%$ ) and first clinical manifestation of genital herpes $(8,2 \%)$.

\section{DISCUSSION}

A total of $680(8 \%)$ of the patients attending the STI clinic were HIV-infected, $3.8 \%$ with a previously known HIV infection and $4 \%$ newly diagnosed cases. Males were predominant in both groups. Newly diagnosed patients were significantly younger and more frequently MSM. Both groups showed a high-risk sexual behaviour pattern referring multiple partners and history of other STIs in the past, the latter being more common in known HIV positive patients. 


\section{GEIDST}

Table 2 - Sexually transmitted infections diagnosed in the study population over a 5-year period (2009-2013).

\begin{tabular}{|c|c|c|c|}
\hline STI (n - \%) & $\begin{array}{c}\text { Total } \\
(n=680)\end{array}$ & $\begin{array}{l}\text { Known HIV infection } \\
\qquad(n=329)\end{array}$ & $\begin{array}{c}\text { Newly diagnosed HIV } \\
\text { infection }(n=351)\end{array}$ \\
\hline 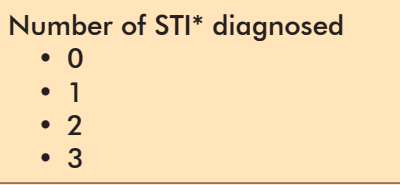 & $\begin{array}{c}410-60 \% \\
223-33 \% \\
42-6 \% \\
5-1 \%\end{array}$ & $\begin{array}{c}181-55 \% \\
130-40 \% \\
16-5 \% \\
2\end{array}$ & $\begin{array}{c}229-65 \% \\
93-26 \% \\
26-7 \% \\
3-1 \%\end{array}$ \\
\hline $\begin{array}{l}\text { Neisseira gonorrhoeae (T) } \\
\text { - Urethral } \\
\text { - Rectal }\end{array}$ & $\begin{array}{l}42-6 \% \\
32-5 \% \\
10-1 \%\end{array}$ & $\begin{array}{l}26-8 \% \\
18-6 \% \\
8-2 \%\end{array}$ & $\begin{array}{l}16-5 \% \\
14-4 \% \\
2-1 \%\end{array}$ \\
\hline $\begin{array}{l}\text { Chlamydia trachomatis }(\mathrm{T}) \\
\text { - Urethral } \\
\text { - Rectal }\end{array}$ & $\begin{array}{c}46-7 \% \\
43-6 \% \\
3\end{array}$ & $\begin{array}{c}23-7 \% \\
22-7 \% \\
1\end{array}$ & $\begin{array}{c}23-7 \% \\
21-6 \% \\
2-1 \%\end{array}$ \\
\hline Molluscum contagiosum & $5-1 \%$ & $2-1 \%$ & $3-1 \%$ \\
\hline $\begin{array}{l}\text { Other } \\
\text { - Male urethritis } \\
\text { - Proctitis } \\
\text { - Trichomoniasis } \\
\text { - HBV infection } \\
\text { - HCV infection }\end{array}$ & $\begin{array}{c}32-5 \% \\
11 \\
9 \\
2 \\
6 \\
4\end{array}$ & $\begin{array}{c}17-4 \% \\
7 \\
8 \\
0 \\
1 \\
1\end{array}$ & $\begin{array}{c}15-4 \% \\
4 \\
1 \\
2 \\
5 \\
3\end{array}$ \\
\hline
\end{tabular}

* Excluding HIV diagnosis.

The most common reason for visiting in both groups was screening, which was more notorious in newly diagnosed patients (80\%). Patients with known HIV infection visited more frequently the STI clinic when symptomatic than newly diagnosed ones (54\% vs $18 \%$ ). More prevalent symptoms in this group were genitourinary discharge and genital warts, while in newly diagnosed patients genital ulcers were the most common clinical presentation. A high prevalence of STI was observed in both groups, with an overall rate of at least one IST (other than HIV) of $40 \%$. Syphilis was the most common STI, and significantly more common in new HIV cases $(21 \%$ vs $15 \%, p<0.05)$. The high rates of co-infection of new HIV cases and recent syphilis has also been found in other series, namely in Portuguese ones. ${ }^{8,9}$

Concomitant STI are commonly observed in newly diagnosed HIV patients and are even more frequently reported in international literature. ${ }^{10,11}$ As previously pointed out, concomitant STI infections, especially when associated with the presence of ulcers, enhance the activation of a number of mechanisms that increase their own transmission. , $12^{2}$

Patients with a known HIV infection maintain high-risk sexual behaviour, as shown by the high incidence of new $\mathrm{STI}$ in this group $(45 \%$ vs $33 \%, p<0.05)$. This issue needs to be addressed not only in STI clinics, but also on HIV clinics. Diagnosis, treatment, and contact tracing of patient partners is essential to reduce the new cases of STI and HIV.[1] Other important factors need to be considered, namely the impact in infertility in both genders, ${ }^{13}$ morbidity, and increased susceptibility to HIV infection. ${ }^{12}$

MSM were highly represented in both groups of patients, as often reported. The number and type of STI diagnosed in this study is in agreement with other reports where STI such as syphilis, genital warts, and gonorrhoea are also commonly diagnosed. 8,14

Management of sexual partners is crucial to limit the spreading of STI and the impact on public health. Patients with either a known or newly diagnosed HIV infection should be important STI clinic targets.

In our study the number of partner referrals was low in both groups ( $4 \%$ and $10 \%$ respectively). More efforts are needed to improve these numbers. Recently, internet-based notification systems for verified diagnoses of STI/HIV have been developed. These systems seem to be a valuable novel tool for notification by patients and providers. ${ }^{15}$

\section{STUDY LIMITATIONS}

We acknowledge the limitations of our study, namely its retrospective nature. Data concerning virologic and immunologic status was not available, limiting a more detailed epidemiologic characterization and also the analysis of the contribution of HIV-induced immunosuppression to the clinical expression of certain STIs, namely herpes and papilloma virus infections.

Moreover, persons engaged in high-risk sexual behaviour 
are more prone to return and repeat STI tests contributing to a possible selection bias.

\section{CONCLUSIONS}

Individuals with STIs are at high risk to acquire and/or transmit HIV infection to sexual partners. Several studies show the association between HIV and other STIs. Conversely, the prevalence of STIs changes according to the study population. In our study population, patients with known HIV infection had a higher number of STIs, both in the past and present, showing an over-time pattern of high-risk sexual behaviour. Newly diagnosed HIV patients were significantly younger and more frequently MSM, which may reflect an increase in the risk of sexual behaviour in this population. These patients were more often referred by partners or sought for asymptomatic screening than those with a known HIV infection; however, partner referral remains low for both groups.

Intensified and innovative efforts in prevention within these specific risk groups need to be taken, namely education programs directed to the sexually active population as well as health professionals. Another necessary intervention is to diffuse more information to seropositive patients about the risk of transmission of both HIV and other STI and a possible negative impact of a new IST on their HIV infection status. Overall, we need to put more effort into preventing STI, as well as treating and possibly reducing new HIV infections.

Conflitos de interesse: Os autores declaram não possuir conflitos de interesse.

Suporte financeiro: $O$ presente trabalho não foi suportado por nenhum subsídio ou bolsa.

Confidencialidade dos dados: Os autores declaram ter seguido os protocolos do seu centro de trabalho acerca da publicação dos dados de doentes.

Protecção de pessoas e animais: Os autores declaram que os procedimentos seguidos estavam de acordo com os regulamentos estabelecidos pelos responsáveis da Comissão de Investigação Clínica e Ética e de acordo com a Declaração de Helsínquia da Associação Médica Mundial

Conflicts of interest: The authors have no conflicts of interest to declare.

Financing Support: This work has not received any contribution, grant or scholarship.

Confidentiality of data: The authors declare that they have followed the protocols of their work center on the publication of data from patients.

Protection of human and animal subjects: The authors declare that the procedures followed were in accordance with the regulations of the relevant clinical research ethics committee and with those of the Code of Ethics of the World Medical Association (Declaration of Helsinki).

\section{REFERENCES}

1. Steen R, Wi TE, Kamali A, Ndowa F. Control of sexually transmitted infections and prevention of HIV transmission: mending a fractured paradigm. Bull World Health Organ. 2009,87:858-65.
2. Kalichman SC, Cain D, Simbayi LC. Behavioral changes associated with testing HIV-positive among sexually transmitted infection clinic patients in Cape Town, South Africa. Am J Public Health. 2010; 100:714-9.

3. Cohen MS. HIV and sexually transmitted diseases: lethal synergy. Top HIV Med. 2004;12:104-7.

4. Cunha A, Santos R, Fernandes C, Rodrigues A, Cardoso J. Doenças de transmissão sexual como diagnóstico inicial de infecção VIH. Rev Soc Port Dermatol Venereol. 2005; 63:355-8.

5. Pereira B, Fernandes C, Nachiambo E, Santos R, Rodrigues A, Cardoso J. Novas infecções sexualmente transmissíveis em doentes seropositivos para o VIH. Rev Soc Port Dermatol Venereol. 2006; 64:347-54.

6. Direcção Geral da Saúde. Infeção VIH, SIDA e tuberculose em números - 2014. Programa Nacional para a infeção VIH/SIDA. Lisboa: DGS; 2014.

7. Santo I, Azevedo J, Cardoso J. A consulta de doenças sexualmente transmissíveis do Centro de Saúde da Lapa. Caracterização da população utente e padrão epidemiológico das IST. Rev Soc Port Dermatol Venereol. 2007; 65:383-94.

8. Ferreira O, Lisboa C, Magalhães Ramos F, Azevedo F. Sífilis numa consulta de infecções sexualmente transmissíveis. Rev Soc Port Dermatol Venereol. 2012;70:99-104.

9. Pereira B, Fernandes C, Nachiambo E, Santos R, Rodrigues A, Cardoso J. Sífilis recente: padrão epidemiológico da consulta de doenças sexualmente transmissíveis do Hospital de Curry Cabral (2003-2005). Rev Soc Port Dermatol Venereol. 2006; 64:355-9.

10. Arora P, Nagalkerke N, Jha P. A systematic review and meta-analysis of risk factors for sexual transmission of HIV in India. PLoS One. 2012; 7:e44094.

11. Lee PM, Ho KM. Risk factors associated with human immunodeficiency virus (HIV) infection among attendees of public sexually transmitted infection clinics in Hong Kong: implications for HIV prevention. Hong Kong Med J. 2008; 14:259-66.

12. Sarkar S, Shrimal A, Das J, Choudhury S. Pattern of sexually transmitted infections: a profile from a sexually transmitted infections clinic of a tertiary care hospital of eastern India. Ann Med Health Sci Res. 2013; 3:206-9.

13. Johnson HL, Ghanem KG, Zenilman JM, Erbelding EJ. Sexually transmitted infections and adverse pregnancy outcomes among women attending inner city public sexually transmitted diseases clinics. Sex Transm Dis. $2011 ; 38: 167-71$.

14. Diaz A, Junquera ML, Esteban V, Martínez B, Pueyo I, Suarez J, Ureña et al. HIV/STI co-infection among men who have sex with men in Spain. Euro Surveill. 2009; 14. pii: 19426.

15. Götz HM, van Rooijen MS, Vriens P, Op de Coul E, Hamers $M$, Heijman $T$, et al. Initial evaluation of use of an online partner notification tool for STI, called 'suggest a test': a cross sectional pilot study. Sex Transm Infect. 2014; 90:195-200. 